\title{
Pattern of morbidity among female textile workers in Puducherry, South India
}

\author{
Punitha Kumary P*, Subitha L, Gautam Roy
}

Punitha Kumary. P*, Subitha L, Gautam Roy.

Department of Community Medicine, PSG Institute of Medical Science and Research, Peelamedu, Coimbatore641 004, Tamil Nadu, INDIA.

\section{Correspondence}

Punitha Kumary ${ }^{*}$, Assistant Professor Department of Community Medicine, PSG Institute of Medical Science and Research, Peelamedu, Coimbatore641 004, Tamil Nadu, INDIA.

Phone no: 9345704994

Email: punithakumary.p@gmail.com

History

- Submission Date: 03-09-15:

- Review completed: 18-06-16;

- Accepted Date: 22-06-16.

DOI : 10.5530/ijmedph.2016.3.9

Article Available online

http://www.ijmedph.org/v6/i3

Copyright

(C) 2016 Phcog.Net. This is an openaccess article distributed under the terms of the Creative Commons Attribution 4.0 International license.

\begin{abstract}
Introduction: The Indian textile industry is one of the largest in the world and accounts for $21 \%$ of the total employment generated in the Indian economy. ${ }^{1}$ The current burden of occupational health diseases is estimated to be around 18 million cases. ${ }^{2}$

Objectives: To study the pattern of diseases which are common among textile workers.

Methods: A descriptive study was conducted among 179 women working in a textile industry in Puducherry. After obtaining informed consent, data was collected using a structured questionnaire. This was followed by systemic examination of Sensory systems (visual acuity testing using Snellen's chart, hearing tests using Tuning fork), Respiratory system (using Peak Expiratory Flow Meter) and Musculoskeletal system (Straight leg raising test and others). Data was analyzed using SPSS version 19:IBM.

Results: $70 \%$ of the participants belonged to the age group 21-40 years and more than half of the women were employed for 5-9 yrs. One fourth of the subjects had complaints of musculoskeletal problems such as joint pain, myalgia and chronic low backache. Respiratory infections and other complaints were also reported. Nearly $40 \%$ of the study subjects had myopia, 3\% had abnormality in hearing and Peak Expiratory Flow Rate was reduced in 53\% of cases.
\end{abstract}

Conclusion: The present study shows that myopia is common among the workers, along with abnormal lung function, which indicates a need for, preplacement and periodic medical examination to rule out ophthalmic and pulmonary morbidities.

Key words: Morbidity pattern, Female textile workers, Pondicherry, South India, Visual problems.

\section{INTRODUCTION}

The Indian textile industry is one of the largest in the world with a massive raw material and textiles manufacturing base. ${ }^{1}$ Indian economy is largely dependent on the textile manufacturing and trade in addition to other major industries. About $27 \%$ of the foreign exchange earnings are on account of export of textiles

The textile industry accounts for $21 \%$ of the total employment generated in the Indian economy. Around 35 million people are directly employed in the textile manufacturing activities. Indirect employment including the manpower engaged in agricultural based raw-material production like cotton and related trade and handling could be around another 60 million. ${ }^{1}$

The current burden of occupational health diseases is estimated to be around 18 million cases and among them, the annual incidence of chronic respiratory disorders is forty five lakhs, dermatitis is thirty lakhs and musculoskeletal disorders is seventy five thousand cases. Thirty percent of hospital admissions and twenty eight percent of limb injuries are related to occupation diseases morbidities. $^{2}$ and clothing alone. ${ }^{1}$
A sick-leave-based case-control study, reported that the main morbidities among these workers are respiratory diseases, accidents and injuries, musculoskeletal and connective tissue disorders. The morbidities also increased with age and sex; morbidity among women was 1.5 higher than among men. ${ }^{3}$ Another case control study reported the that aches (19.4\%), respiratory $(12.1 \%)$ and fever $(7.7 \%)$, was higher in textile workers than in the comparative group. ${ }^{4}$ A cross sectional study done at Wardha reported that chronic bronchitis, eosinophilia 19.8\%, iron deficiency anemia, refractive errors, upper respiratory tract infection, low back pain were common in this

Puducherry is a Union Territory with Legislature extending over an area of $479 \mathrm{Sq} . \mathrm{kms}$ located $160 \mathrm{Kms}$ south of Chennai, with the population of 950,289 of which male and female were 468,258 and 482,031 respectively. $69.16 \%$ lives in urban regions and 30.84 $\%$ lives in rural areas of Pondicherry as per Govt of India Ministry of MSME 2012. Pondicherry has nearly 8708 small scale industries apart from 45 large scale and 80 medium scale industries. Taken together, these provide employment to more than 80,000 people. Some of the significant industries in group of workers. ${ }^{5}$

Cite this article : Punitha K, Subitha L, Roy G. Pattern of morbidity among female textile workers in Puducherry, South India. J. Med. Public Health, 2016; 6(3):140-3. 
Pondicherry are chemicals, textiles, light engineering, metals, and food processing. These were the industries which contribute to the economic growth of Pondicherry as well as overall health status of the community. ${ }^{6}$ As textile industry is one of the significant industries in Puducherry, that contribute to the economic growth and give employment to majority of people, a study on morbidity pattern in textile industry would help us to indentify the common morbidity prevailing among them, especially refractive error, hearing defect, musculoskeletal problems, infections related to respiratory system, reproductive system etc.

Women workers, they contribute significantly to national development by performing both remunerated/paid and unremunerated/unpaid work. They also struggle to combine their roles to look after their families. Women household workers have a double burden as there is greater demand for their skills as care-givers and service workers outside home. ${ }^{7}$ Very few studies have been done to describe the morbidity status of women working in textile industry in southern India. It is in this context that the present study was carried out with an objective to assess the morbidity pattern among female textile workers in Puducherry.

\section{MATERIALS AND METHODS}

This descriptive study was conducted in the year 2011 from April-June. There were five large scale/Public sector and seven medium scale textile industries in Pondicherry, out of these textile industries this textile industry " $\mathrm{x}$ " was chosen by purposive sampling. This industry exclusively employs female workers. It produces cotton and jute products like bags and clothes. Calculated sample size was 170 subjects based on estimated $37 \%$ prevalence rate (prevalence of back pain), ${ }^{5}$ precision of $20 \%$. All subjects in the industrial unit were invited to participate in the medical evaluation.

A structured questionnaire was prepared, piloted and pre tested. The questionnaire included socio-demographic details of the participant, nature of job, duration of employment, presenting complaints and symptoms pertaining to vision, hearing, respiratory ailments, skin problems, musculoskeletal disorders, etc. Modified Prasad's classification was used for calculating SES. The study was approved by the institute Scientific and Ethics committee. Administrative permissions were obtained from the management after explaining the purpose of the study.

After obtaining the informed consent verbally, the participants were interviewed as per the questionnaire. Height in meters, weight in $\mathrm{Kg}$ and blood pressure measurement was done using stadiometer and weighing machine (Dr Gene bathroom weighing scale machine). Random Blood sugar estimation was done by using glucometer (Accu-chek Active Model:GU). This was followed by systemic examination of Sensory systems (visual acuity testing using Snellen's chart, hearing tests using Tuning fork- Aluminum Clinical Grade Nerve/Sensory Tuning Fork), Respiratory system (using Peak Expiratory Flow Meter) and Musculoskeletal system (Straight leg raising test and others). Subjects were also subjected to Spirometry test using Peak Expiratory Flow meter. A trained Technician from Pulmonary medicine collected data using Peak Expiratory Flow and an Optometrist collected data on vision using Snellen's chart. Predicted PEFR for each subject was calculated based on the formula: $3.310 \mathrm{x}$ height (cms) - $1.865 \mathrm{x}$ age (years) - 81.0. (Ranga Rao et al, 2002). ${ }^{8}$ If the PEFR of the subject is $<80 \%$ of the predicted value then that PEFR is considered as abnormal.

\section{Statistical analysis}

The collected data was entered and analyzed using SPSS version 19:IBM. (Statistical Package for Social Sciences). The findings were expressed in terms of proportions or percentages and Mean \pm SD as appropriate.

\section{RESULTS}

There were totally 185 female workers in that industry. A total of 179 subjects participated in the study and the rest of the female workers left their job just before the start of the study. Mean age of the participants was $34.94 \pm 8.9$. Among the study subjects $126(70 \%)$ were in the age group of 21-40, 141(79\%) were married, 65 (36.3\%) had higher education. More than fifty percent were in class IV SES ( Per capita income Rs:480-959), lived in semipucca house, and $75 \%$ were from nuclear family. Majority $(85 \%)$ of the workers were from the urban area (Table 1). More than half of the women were employed for 5-9 yrs. Most (68.2\%) of the study subjects were employed in stitching, while the other types of job profile included cutting (11.7\%), packing (3.3\%) and general assistance (Table 2). Around $40.8 \%$ were with normal weight, $39.1 \%$ pre-obese, $12.8 \%$ obese, $6.7 \%$ underweight and $0.6 \%$ overweight. Around 129 (72.1\%) subjects were with normal blood pressure, $20.7 \%$ pre hypertensive and $7.3 \%$ were hypertensive. Around 2.2\% had abnormal random blood sugar values of $>140 \mathrm{mg} \%$.

One fourth of the subjects (27.4\%) had complaints of musculoskeletal problems such as joint pain (9.5\%), myalgia (8.9\%) and chronic low

Table 1: Socio-demographic details of the study subjects $(n=179)$

\begin{tabular}{|c|c|}
\hline Socio-demographic variables & $\mathrm{N}(\%)$ \\
\hline \multicolumn{2}{|l|}{ Age } \\
\hline$<=20$ & $9(5)$ \\
\hline $21-40$ & $126(70.4)$ \\
\hline$>40$ & $44(24.6)$ \\
\hline \multicolumn{2}{|l|}{ Marital status } \\
\hline Married & $141(78.8)$ \\
\hline Unmarried & $32(17.9)$ \\
\hline Widow & $6(3.3)$ \\
\hline \multicolumn{2}{|l|}{ Education } \\
\hline Unemployed & $13(7.3)$ \\
\hline Primary & $32(17.9)$ \\
\hline Middle & $48(26.8)$ \\
\hline High & $65(36.8)$ \\
\hline Higher secondary & $16(8.9)$ \\
\hline Degree/college & $5(2.8)$ \\
\hline \multicolumn{2}{|l|}{ Socioeconomic status ${ }^{\star}$} \\
\hline Class I & nil \\
\hline Class II & 26(14.5) \\
\hline Class III & $41(22.9)$ \\
\hline Class IV & $92(51.4)$ \\
\hline Class V & $20(11.2)$ \\
\hline \multicolumn{2}{|l|}{ Domicile } \\
\hline Urban & 153(85.5) \\
\hline Rural & $26(14.5)$ \\
\hline \multicolumn{2}{|l|}{ Housing } \\
\hline Kutcha & $36(18.7)$ \\
\hline Semipucca & $100(51.8)$ \\
\hline Pucca & $43(22.3)$ \\
\hline \multicolumn{2}{|l|}{ Family type } \\
\hline Nuclear & $135(75.4)$ \\
\hline Joint & $44(24.6)$ \\
\hline Total & $179(100)$ \\
\hline
\end{tabular}

* Modified Prasad's classification. 
Table 2: Distribution of subjects according to work profile

\begin{tabular}{lc}
\multicolumn{1}{c}{ Characteristics } & N (\%) \\
\hline Work experience in years & \\
$\leq 4$ yrs & $63(35.2)$ \\
$5-9$ yrs & $99(55.3)$ \\
$\geq 10$ yrs & $17(9.5)$ \\
Type of work & \\
Cutting & $21(11.7)$ \\
Stitching & $122(68.2)$ \\
Helping & $30(16.8)$ \\
Packing & $6(3.3)$ \\
Total & $\mathbf{1 7 9 ( 1 0 0 )}$ \\
\hline
\end{tabular}

Table 3: Pattern of morbidity on clinical examination of subjects $(\mathbf{N}=179)$

\begin{tabular}{lc}
\multicolumn{1}{c}{ Examination Findings } & $\mathrm{N}(\%)$ \\
\hline Vision testing (Snellen's) & $108(60.3)$ \\
Normal & $71(39.7)$ \\
Refractive error & \\
Hearing tests (Tuning fork tests) & $174(97.2)$ \\
Normal & $5(2.8)$ \\
Abnormal & \\
Respiratory system (Peak expiratory flow meter) & $84(47)$ \\
Normal ( $>80 \%$ of predicted value) & $93(53)$ \\
Abnormal $(<80 \%$ of predicted value) & \\
\hline
\end{tabular}

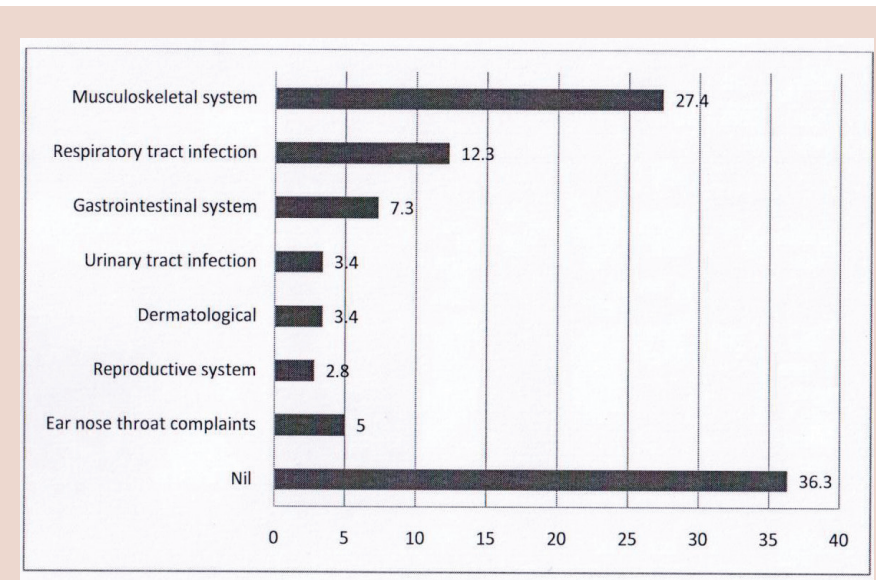

*Values given are in percentages

Figure 1: Morbidity pattern among the textile workers $(n=179)$

backache (8.9\%). Around $12.3 \%$ had respiratory tract infection and 7.3\% had gastric problem like acid peptic disease. Problems of ear, nose and throat like sinusitis was observed in $5 \%$ of subjects. Other problems were related to reproductive system (leucorrhoea in $2.8 \%$ ), dermatological (3.4\%) and urinary tract infection (3.4\%) (Figure 1).

On clinical examination nearly 71 (40\%) of the study subjects had myopia, $3 \%$ had abnormality in hearing (Table 3). Though subjects had complaints of low back ache there was no abnormality on detailed evaluation. The peak expiratory flow rate was abnormal in $53 \%$ of cases.

\section{DISCUSSION}

This study showed that $27 \%$ of the workers had musculoskeletal complaints of which myalgia; arthralgia and low back ache were common. This is similar to other studies. ${ }^{4,6,8,17,18}$ Present study showed respiratory tract infection $12.3 \%$ and acid peptic disease $7.3 \%$, this was also in accordance with the study done in Rajasthan among textile workers males and females in $2005 .^{3}$

In this study on examination, $40 \%$ of the study subjects had refractive error, which is higher compared to other studies. This has to be addressed at the earliest as most (68\%) of the workers were involved in fine work (stitching). Unless this problem is addressed it may lead to injuries. Hearing abnormality was lower compared to other studies. ${ }^{9}$ This may be due to reduced noise exposure due to different levels of machinery involved in various processing and manufacturing.

The International Labour Organization estimates that $40 \%$ of all costs related to work-related injuries and diseases are due to musculoskeletal disorders. Among these, low back pain is the most common. Proper ergonomic measures has to be taken by the company to enable the worker to work comfortably and to prevent all the musculoskeletal complaints, and other health issues. ${ }^{15,16}$

As most (70\%) of the study subjects were in the productive age group (21-40 yrs) their health problems like refractive error, musculoskeletal and abnormal PEFR has to be treated and followed up regularly. This not only affects their personal health and family but also the productivity of the company in the long run. ${ }^{1,3}$

More than half of the study subjects had abnormal PEFR. This is high compared to the study done among textile workers in Karachi both genders in $2009 .{ }^{10}$ As all the study subjects were women; they are subject to the duel burden of indoor air pollution both at home and at the work place. Studies have shown that women using biofuel, kerosene, LPG and mixed fuel had abnormal PEFR. ${ }^{(11-14)}$ However for detailed assessment of the pulmonary function; these subjects were referred to tertiary centre for further evaluation.

Occupational health studies are difficult to perform as there is an amount of fear and panic on the management side, due to issues related to morbidity of their workers and the associated legal issues. There may be some resistance from the industries sector, but as evident from this study, there is a need for regular pre-placement and periodic medical examination for this group of workers.

\section{CONCLUSION}

The present study found that most common problem was musculoskeletal and nearly $40 \%$ of the study subjects had myopia. This shows that the workers are unaware of ergonomic postures and medical evaluation. Hence, there is need for preplacement and periodic medical examination to be done by doctor in the industry clinic. This would help in early diagnosis and treatment of morbidities prevailing among the employees.

\section{ACKNOWLEDGEMENT}

We thank Ford foundations for selecting this under epidemiological grant.

\section{CONFLICT OF INTEREST}

Nil.

\section{ABBREVIATION USED}

PEFR - Peak expiratory flow rate.

\section{REFERENCES}

1. Ministry of Textiles, Govt of India.

2. Mishra AK, Rotti SB, Sahai A, Mohan M, Danabalan. Epidemiological study of chronic bronchitis among textile workers in Pondicherry. Indian J Community Med. 2004;29(4):166-87. 
3. Ustinaviciene R, Piesine L. Morbidity of textile industry workers in Kaunas Medicina (Kaunas). 2007;43(6):495-500.

4. Madhu B. Singh, RanjanaFotedarandJ. Lakshminarayana. Occupational Morbidities and their Association with Nutrition and Environmental Factors among Textile Workers of Desert Areas of Rajasthan, J Occup Health. 2005;47(5):371-7 http:// dx.doi.org/10.1539/joh.47.371

5. Rajanarayanan RT, Mrinalini CP, Sanjay PZ, Vijay YB. Morbidity profile of cotton textile workers. Indian J Community Med. 2001;26(1):26-30.

6. Govt of India Ministry of MSME. Brief Industrial profile of Puducherry 2012 [internet] available from : http://dcmsme.gov.in/dips/IPS\%20Puducherry\%20 2012_tn.pdf

7. Chapter 2 Unorganised women workers in India. [internet] available from: http:// shodhganga.inflibnet.ac.in/bitstream/10603/30220/8/08_chapter\%202.pdf

8. Ranga Rao TV, Sinha VN, Lanjewar P. Specialized training programme on occupational and environmental medicine. New Delhi: Ministry of Labour, Government of India. 2002. PMid:27365655

9. 9. Deepti M. Kadeangadi, A.S. Wantamutte, N.D. Zingade, M.D. Mallapur, M.S. Shivaswamy. Morbidity pattern in textile weavers of urban Belgaum: A community based cross sectional study.

10. Rec Res Sci Tech.2010; 2: 01-04.Asaad AN, Zafar F, Muhammad MK, Nalini Sk. Pattern and predictors for respiratory illnesses and symptoms and lung function among textile workers in Karachi, Pakistan.Occup Environ Med doi:10.1136/ oemed-2011-100561 http://dx.doi.org/10.1136/oemed-2011-100561
11. Ranga Rao TV, Sinha VN, Lanjewar P. Special-ized training programme on occupational and environmental medicine. New Delhi: Ministry of Labour, Government of India. 2002.PMid:27365655.

12. Behera D. An analysis of effect of common domestic fuels on respiratory function. Indian J Chest dis Allied Sci. 1997;39:235-43.PMid:9654820.

13. Sukhsohale DN, Narlawar WU, Thakre SS, Ughade NS. Peak Expiratory Flow Rates Among Women Exposed To Different Cooking Fuels In Rural India. Southeast Asian J Trop Med Public Health. 2013;44(5):(900-905.)

14. Pravin NY, Keerti SJ. Morbidity profile of cotton mill workers. Indian J Occup Environ Med. 2010;14(3):94-6. http://dx.doi.org/10.4103/0019-5278.75697 ; PMid:21461162 PMCid:PMC3062022

15. Rajgopal T. Musculoskeletal disorders. IndianJ Occup Environ Med. 2000;4:2-3

16. Saiyed HN, Tiwari RR. Occupational Health Research in India. Industrial Health. 2004;42:141-8. http://dx.doi.org/10.2486/indhealth.42.141

17. Thangaraj P, Kannappan S, Chacko TV. Occupation-Related Health Status of Women Textile Workers in Tamil Nadu. Int J Preven Curat Comm Med. 2015;1(4):145-9.

18. Sridevi D, Radhai Sri S. Health Status of Spinning Women Workers. International Journal of Science and Research. 2014;3(12): 2568-70.

Cite this article : Punitha K, Subitha L, Roy G. Pattern of morbidity among female textile workers in Puducherry, South India. J. Med. Public Health, 2016; 6(3):140-3. 